\title{
BIRD'S EYE VIEW ON HERBAL MARKET PRODUCTS IN INDIA FOR THE TREATMENT OF OBESITY
}

\author{
*Jagtap Chandrashekhar ${ }^{\mathrm{a}}$, Patil Rajeshree ${ }^{\mathrm{b}}$, Gokarn Rohit ${ }^{\mathrm{a}}$, Rajput Dhirajsingh ${ }^{\mathrm{a}}$, Prajapati Pradeepkumar ${ }^{\mathrm{a}}$ \\ ${ }^{a}$ Department of Rasashastra and Bhaishajya Kalpana including Drug Research \\ ${ }^{\mathrm{b}}$ Department of medicinal plants.
}

Institute for Post Graduate Teaching and Research in Ayurveda, Gujarat Ayurved University, Jamnagar, 361 008, Gujarat, India

*Corresponding Author's e-mail: drshikhar84@gmail.com, Contact: + 91-9725519408

\begin{abstract}
Along with advancements in technology, herbal preparations are attracting the pharmaceutical markets due to their wider acceptance and increasing demand. Many herbal preparations and raw herbs are being used for the treatment of obesity since centuries. Main objective of the present review is to focus on the commonly used herbs and their formulations in Indian market for the treatment of obesity. For the review of different formulations available online, a famous website www.alibaba.com has been searched for 'herbals for weight loss' especially in India. List of some herbal drugs manufacturers, suppliers and exporters has also been provided for the convenience of researchers in this area. Anti-obesity herbal formulations are available in the form of tablets, capsules, softgel capsules, powders, extracts, oil, ointments, creams, gel, and tea bags etc. From the present review it is concluded that there is great market potential for the herbal preparations used for weight loss.

Key words: Guggulu, herbal market, hyperlipidemia, metabolic syndrome, obesity
\end{abstract}

\section{INTRODUCTION}

Obesity and the metabolic syndrome are the most common nutritional disorders in developed countries. Worldwide, it is the result of modernization and urbanization. It has been reported that obesity and its metabolic complications cause both substantial socio-economic and physical burden on society ${ }^{1},{ }^{2}$. Obesity is the accumulation of the fat in the body over the limit leading to serious adverse effects on body as well as on mind. The energy intake coming from food that the body does not use is stored as fat and leads to overweight. Two main factors responsible for this are: 1) an increased intake of energy rich foods that are high in fat, salt and sugars but low in vitamins, minerals and other micronutrients; and, 2) a decrease in physical activity due to the increasingly sedentary nature of many forms of work, changing modes of transportation, and increasing urbanization. Obesity increases the risk of developing many health problems which include ischeamic heart disease, myocardial infarction, stroke, type 2 diabetes, hypertension, hypercholesterolemia, certain cancers, sleep apnea, osteoarthritis, gout and psychological and emotional effect ${ }^{3}$.

Overweight and obesity are the fifth leading risk for global deaths. At least, 2.8 million adults die each year as a result of being overweight or obese. WHO global estimates for the year 2008, reported 1.5 billion people were overweight, of these, over 200 million men and nearly 300 million women were obese. Overall, more than one in ten of the world's adult population was obese ${ }^{4}, 5$.

The important measures to be undertaken for the treatment of obesity include dietary changes, exercise and activity, behavior changes, prescriptions of weight loss medications and weight loss surgery ${ }^{6}$. But due to busy schedules and sedentary lifestyle follow-up the first two methods never seems to be practiced in a regular manner. Considering the cost involved the weight loss surgery is not preferred by many. There is a gradual shift towards an increased use of drugs treatment for weight loss but unfortunately, despite short term benefits, it is often associated with rebound weight gain after the cessation of drug use, side effects from the medication, and the potential for drug abuse ${ }^{7}$. In such a scenario, an inexpensive option to help weight reduction in the weight management programme is an intervention which is based on nutritional ${ }^{8}$.

Herbal medicines have played a significant role in the management of both minor and major health problems. From recent few decades, they are being extensively utilized worldwide due to their cost effectiveness, less to no toxic side effects in comparison with many chemically synthesized drugs ${ }^{9}$. The World Health Organization (WHO) estimates that 80 percent of the world's population presently uses herbal medicine for some aspect of primary health care. Many Complementary and Alternative Medicine (CAM) therapies used across the different countries contain the plants based dietary supplements which have potential to reduce increased weight ${ }^{10}$. Some recent preliminary reports suggested that some herbs and other natural substances are effective in appetite reduction and promotion of significant weight loss is encouraging ${ }^{11}$. There are some reviews that examined the efficacy of herbal medicines used in the treatment of obesity on experimental models, humans, including clinical trials ${ }^{12}, 13$, ${ }_{14},{ }^{15}$. In the present study, some herbal plants commonly utilized in the treatment of obesity and various market products for obesity have been presented. This will give a precise idea to researchers as well as to producers and suppliers of herbal products regarding the potential of these herbal gems. 


\section{HERBAL PLANTS USED FOR OBESITY}

The materials like vegetables, spices, fruits, pulses, tea etc which are used as a nutrient or as a source of food can prove to be useful in the treatment of obesity [Table 1]. These drugs have their own importance with regards to their local availability, lesser side effects, economically cheapness and faith of the people in traditional medicine. Some of the phyto constituents present in these herbs such as inulin, pectin, flavonoids, saponins, tannins, dietary fibres, phytosterols/stanols, dietary carotenoids, polyphenols, plant indoles etc, have potential hypolipidemic properties by different mechanisms such as reducing atherosclerosis by inhibiting platelet aggregation, increasing fibrinolysis, enhancing antioxidant activity, reducing serum lipids in general to lower cholesterol levels, controlling appetite, fat metabolism, adipocyte differentiation, fat absorption, energy metabolism, thermogenesis (generation of heat) etc. , which may lead to weight loss ${ }^{16}$.

Table 1: List of some herbal plants being utilized for the treatment of obesity

\begin{tabular}{|c|c|c|}
\hline Botanical name & English/Common name & Photograph \\
\hline Allium sativum $\mathrm{L}$. & Garlic & \\
\hline Anacardium occidentale $\mathrm{L}$. & Cashew nut & \\
\hline Capsicum frutescens $\mathrm{L}$. & Red pepper, Chili & \\
\hline Chicorium intybus L. (seed) & Common chicory & \\
\hline $\begin{array}{l}\text { Cucurbita maxima } \\
\text { (seed) }\end{array}$ & Pumpkin, Winter squash & \\
\hline Foeniculum vulgare (Gaert.) seeds & Fennel, sweet fennel & \\
\hline Panax quinquefolium $\mathrm{L}$. & American ginseng & \\
\hline Zingiber officinale & Ginger & \\
\hline Thymus vulgaris & Common thyme & \\
\hline
\end{tabular}




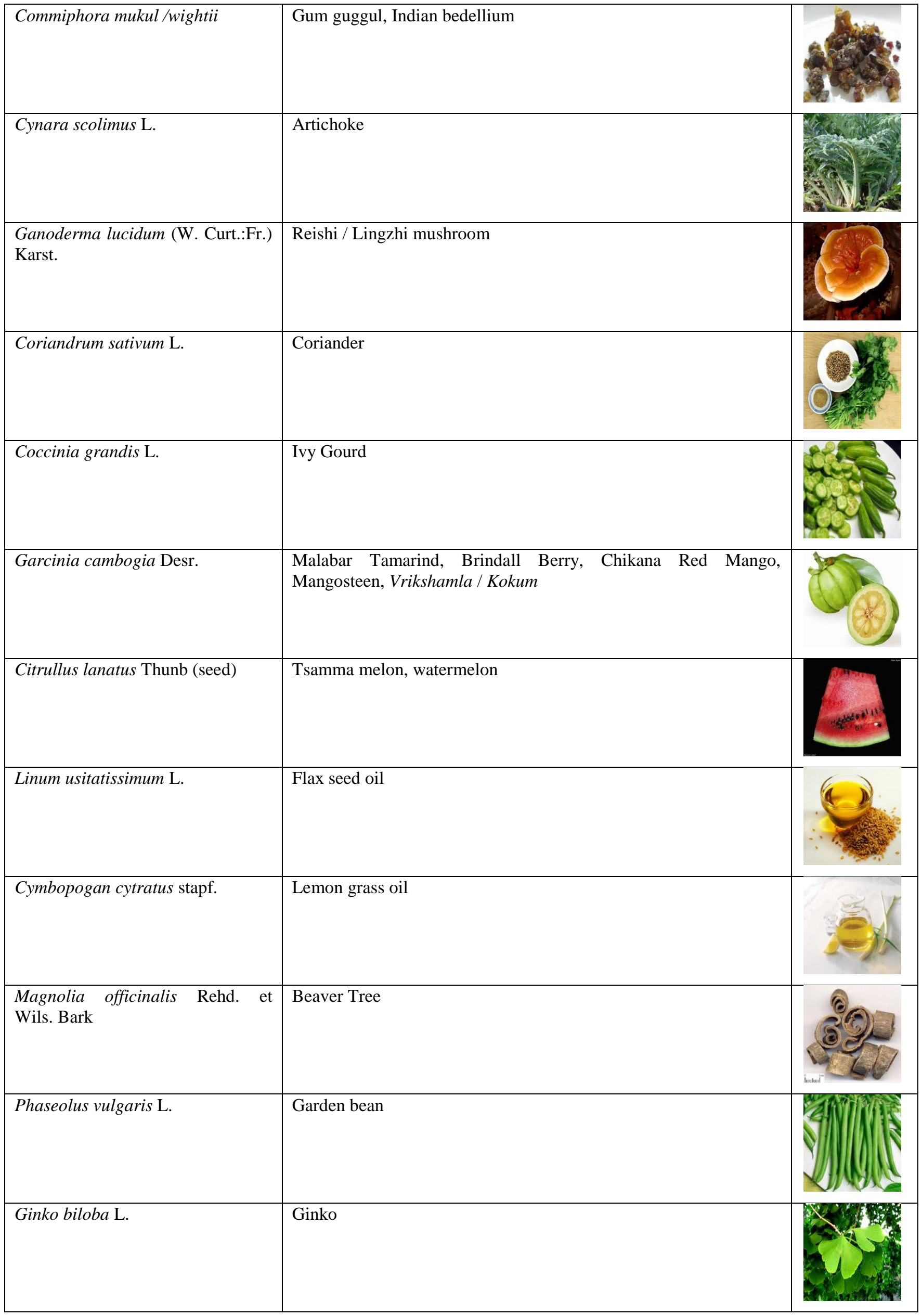




\begin{tabular}{|l|l|l|}
\hline Caralluma fimbriata Wall. & Caralluma & \\
\hline Lagenaria siceraria L. & Bottle Gourd, trumpet gourd & \\
\hline
\end{tabular}

HERBAL BASED ANTI-OBESITY PREPARATIONS AVAILABLE IN INDIAN MARKET

India is have well-recorded and traditionally well-practiced knowledge of herbal medicine. Many herbs of medicinal importance have been in use in one form or another, under indigenous systems of medicine like Ayurveda, Siddha and Unani. Seeking the economic growth potential and the global importance, Indian pharmaceutical companies are now producing, supplying and marketing the herbs, their derivatives like extracts and formulations. In India, there are about 7000 firms manufacturing traditional medicines ${ }^{17}$. Table 2 enlisted the companies associated with manufacturing, supplying and exporting the herbs, herbal preparations based on them and their derivatives ${ }^{18}$.

Table 2: List of herbal medicines manufacturers, suppliers, and exporters

\begin{tabular}{|c|c|c|c|}
\hline S No. & Manufacturers & Suppliers & Exporters \\
\hline 1 & $\begin{array}{l}\text { Harshal Ayur Pharma, Nanital, } \\
\text { Uttaranchal }\end{array}$ & $\begin{array}{l}\text { Yashco Industries Private Ltd, } \\
\text { Mumbai, Maharashtra }\end{array}$ & $\begin{array}{l}\text { Turab H V Herbals (P) Ltd, Nagpur, } \\
\text { Maharashtra }\end{array}$ \\
\hline 2 & $\begin{array}{l}\text { Shiva International, Bellary, } \\
\text { Karnataka }\end{array}$ & $\begin{array}{l}\text { Trient Creation, Mumbai, } \\
\text { Maharashtra }\end{array}$ & Ganga Corporation, , Kochi, Kerala \\
\hline 3 & $\begin{array}{l}\text { Ayrumed Biotec (p) Ltd, Mumbai, } \\
\text { Maharashtra }\end{array}$ & $\begin{array}{l}\text { General Commodities } \quad \text { Ltd, } \\
\text { Bengaluru, Karnataka }\end{array}$ & $\begin{array}{lrr}\text { Mehta } & \text { Trading } & \text { Company, } \\
\text { Ahmedabad, Gujurat } & \end{array}$ \\
\hline 4 & $\begin{array}{lll}\text { Swati } & \text { Ayurvedic } & \text { Products, } \\
\text { Ghaziabad, Uttar Pradesh } & \end{array}$ & Swarita Exports, Gurgaon & $\begin{array}{l}\text { Shree Baidyanath Ayurved Bhawan } \\
\text { (p) Ltd, Jhansi, Uttar Pradesh }\end{array}$ \\
\hline 5 & $\begin{array}{l}\text { Garlico Herbal Concentrate, } \\
\text { Mandsaur, Madhya Pradesh }\end{array}$ & $\begin{array}{l}\text { Shushtri } \quad \text { Industries, } \\
\text { Mumbai, Maharashtra }\end{array}$ & Cochin Ayurvedic Center, \\
\hline 6 & $\begin{array}{l}\text { Turab H V Herbals (p) Ltd, Nagpur, } \\
\text { Maharashtra }\end{array}$ & $\begin{array}{l}\text { Himalaya Herbal Healthcare, } \\
\text { Makali, Bangalore }\end{array}$ & Herb India.com \\
\hline 7 & $\begin{array}{l}\text { Varun Biocel (p) Ltd, Varanasi, Uttar } \\
\text { Pradesh }\end{array}$ & - & Krishna Herbal Company \\
\hline 8 & $\begin{array}{l}\text { Prakruticure Private Ltd., Mumbai, } \\
\text { Maharashtra }\end{array}$ & - & Lotus Herbals Ltd, New Delhi \\
\hline 9 & $\begin{array}{l}\text { Himalaya Herbal Product, Nurpurm, } \\
\text { Himachal Pradesh }\end{array}$ & - & White Lotus Herbals \\
\hline 10 & $\begin{array}{l}\text { Taj Pharmaceuticals Ltd, Mumbai, } \\
\text { Maharashtra }\end{array}$ & - & - \\
\hline 11 & Indichem, Mumbai, Maharashtra & - & - \\
\hline 12 & Ind Swift limited, Chandigarh & - & - \\
\hline 13 & $\begin{array}{lll}\text { Admark Herbals } & \text { Limited, } \\
\text { Ahmedabad, Gujrat } & \end{array}$ & - & - \\
\hline 14 & $\begin{array}{l}\text { Dave Pharmaceuticals, New Mumbai, } \\
\text { Maharashtra }\end{array}$ & - & - \\
\hline
\end{tabular}

Very large numbers of anti-obesity formulations are available in the market. They are freely accessible through internet and can be ordered online also. List of various formulations and their details are given in Table 3 . 
Table 3: Detailed herbal based fat reducing market preparations in Indian market 19

\begin{tabular}{|c|c|c|c|}
\hline $\begin{array}{l}\text { Market } \\
\text { preparati } \\
\text { on } \\
\text { (Brand } \\
\text { name) }\end{array}$ & $\begin{array}{l}\text { Form } \\
\text { available }\end{array}$ & Supplier & Details \\
\hline $\begin{array}{l}\text { Nutri Slim } \\
\text { Capsules }\end{array}$ & Capsule & $\begin{array}{l}\text { Nutri Thera } \\
\text { Laboratory } \\
\text { Pvt Ltd }\end{array}$ & $\begin{array}{l}\text { Extract from the Acai Berry is an anti-oxidant which increases energy, improves } \\
\text { digestion system and also linked to aiding a healthy and quiet sleep. The pigment } \\
\text { of the berry stimulates fat burning process by combining the body's natural fatty } \\
\text { acids, phytosterols and amino acids together, boosts energy levels and } \\
\text { metabolism, replenishes the skin and postpones aging. }\end{array}$ \\
\hline Trimohills & Tablets & $\begin{array}{l}\text { Isha Agro } \\
\text { Developers } \\
\text { Pvt Ltd }\end{array}$ & $\begin{array}{l}\text { Ingredients not mentioned. 1) Helps preventing fat absorption and deposition } \\
\text { thus help achieve healthy weight; 2) Maintain a healthy blood lipid level and } \\
\text { supports weight management; 3) Improves gastric functions; 4) Helps fighting } \\
\text { fatigue and stress experienced in diet regime. }\end{array}$ \\
\hline $\begin{array}{l}\text { Anti- } \\
\text { Cellulite } \\
\text { Slim oil, } \\
\text { gel and } \\
\text { cream }\end{array}$ & $\begin{array}{l}\text { Cream, } \\
\text { Gel, Oil }\end{array}$ & $\begin{array}{l}\text { V. J. S. } \\
\text { Pharmaceuti } \\
\text { cals Private } \\
\text { Limited }\end{array}$ & $\begin{array}{l}\text { It contains Grapefruit oil and Rose merry oil as fat metabolism stimulator, } \\
\text { Juniper oil and Avocado oil as cell metabolism stimulator, and diuretic; Vitamin } \\
\text { E Oil for cell repair enhancing etc. The combination acts as a diuretic and helps } \\
\text { reduce the fluid build-up in the body. }\end{array}$ \\
\hline $\begin{array}{l}\text { Vilayati } \\
\text { Imli }\end{array}$ & Capsule & $\begin{array}{l}\text { Wilson } \\
\text { Drugs \& } \\
\text { Pharmaceuti } \\
\text { cals Pvt Ltd }\end{array}$ & $\begin{array}{l}\text { Processed extracts of Garcinia cambogia is known to interrupt the synthesis of } \\
\text { various lipids, fatty acids, LDL cholesterol and triglycerides. The herb is best as } \\
\text { an appetite suppressor. The appetite is suppressed by promoting synthesis of } \\
\text { glycogen, thus sending the brain signals of satisfaction and fullness sooner. } \\
\text { The organic acid known as HCA is the primary acid found in the fruit and rind of } \\
\text { G. cambogia. It inhibits lipogenesis, lowers the production of cholesterol and } \\
\text { fatty acids, increases the production of glycogen in the liver, suppresses appetite, } \\
\text { increases body's production of heat by activating the process of thermogenesis. } \\
\text { Specifically, HCA prevents the enzyme from catalyzing the cleavage of citrate to } \\
\text { acetyl coenzyme A and oxaloacetate. This inhibition significantly reduces the } \\
\text { synthesis of triglycerides, cholesterol and body fat, without diminishing energy } \\
\text { production. The result is significant loss of body weight in animals made obese } \\
\text { genetically and by hypothalamic lesions. }\end{array}$ \\
\hline Trimohills & Tablets & $\begin{array}{l}\text { Isha Agro } \\
\text { Developers } \\
\text { Pvt Ltd }\end{array}$ & $\begin{array}{l}\text { Contains Shuddha Guggul, Trikatu Churna, Triphala Churna, Trimad Churna. } \\
\text { Trimad and Triphala help to prevent water retention, a common phenomenon in } \\
\text { obesity. Triphala helps to remove excess fat from the body. Trikatu improves } \\
\text { digestive enzyme action and thus improves fat metabolism. Shuddha } \\
\text { Guggul helps scrap excess fat. }\end{array}$ \\
\hline $\begin{array}{l}\text { Medohar } \\
\text { Guggul }\end{array}$ & Capsule & $\begin{array}{l}\text { Wilson } \\
\text { Drugs \& } \\
\text { Pharmaceuti } \\
\text { cals Pvt Ltd }\end{array}$ & $\begin{array}{l}\text { Each capsule contains processed extracts of Zingiber officinale, Piper nigrum, } \\
\text { Piper longum, Plumbago zeylanica, Cyperus rotundus, Terminalia chebula, } \\
\text { Terminalia bellerica, Emblica officinalis, Embelia ribes, Commiphora mukul. } \\
\text { Good for controlling Obesity and increased cholesterol levels. Based on } \\
\text { stimulating the general metabolism and digestive fire, brings the functioning of } \\
\text { the digestive and biliary systems at their optimum and lowering the lipid levels in } \\
\text { the blood without causing susceptibility to gall stones. }\end{array}$ \\
\hline Herbline & Cream & $\begin{array}{l}\text { Combii } \\
\text { Organochem } \\
\text { Pvt Ltd }\end{array}$ & $\begin{array}{l}\text { A very potent blend of natural fruit oils that helps break the stubborn fat built up } \\
\text { under the dermis. The combination acts as a diuretic and helps reduce the fluid } \\
\text { build-up the } \\
\text { to be used along with Cellulite Gel. }\end{array}$ \\
\hline $\begin{array}{l}\text { Trimayu } \\
\text { Capsules }\end{array}$ & Capsule & $\begin{array}{l}\text { Laxmi } \\
\text { Arogyam } \\
\text { Pvt Ltd }\end{array}$ & $\begin{array}{l}\text { Contains premium quality standardized herbal extracts. Thermo nutrient blends: } \\
\text { special herbal factors help enhance the body's ability to produce energy by } \\
\text { metabolizing } \\
\text { Adrenal support blends: A special blends of rare herbs energizes and further } \\
\text { support healthy adrenal functions. This help to achieve and maintain thermogenic } \\
\text { potential. } \\
\text { Appetite control blends: It contain naturally occurring metabolic factors that } \\
\text { support the brain's "food intake control center". }\end{array}$ \\
\hline
\end{tabular}




\begin{tabular}{|c|c|c|c|}
\hline $\begin{array}{l}\text { Figure } \\
\text { Care }\end{array}$ & Caplet & $\begin{array}{l}\text { BAN Labs } \\
\text { Ltd }\end{array}$ & $\begin{array}{l}\text { It contains herbs like Garcinia cambogia, Premna mucronata, Zinziber officinale } \\
\text { and Plumbago zeylanicum. } \\
\text { These help to regularize fat metabolism, improve liver function \& decrease fat ac } \\
\text { cumulation. Hydroxy-citric- } \\
\text { acid (HCA) which is an active ingredient in Garcinia cambogia converts blood su } \\
\text { gar to glycogen instead of fat, and also reduces appetite by keeping the blood sug } \\
\text { ar levels under control. }\end{array}$ \\
\hline $\begin{array}{l}\text { Moringa } \\
\text { tea bags }\end{array}$ & $\begin{array}{l}\text { Tea } \\
\text { bags/sac } \\
\text { hets }\end{array}$ & $\begin{array}{l}\text { Genius } \\
\text { Nature } \\
\text { Herbs } \\
\text { Private } \\
\text { Limited }\end{array}$ & $\begin{array}{l}\text { Instant mix of Moringa into blood stream. Useful in Diabetes since Moringa has } \\
\text { Hypoglycemic activity. Abundant in crude fiber and Protein, can also be used for } \\
\text { controlling blood pressure. Used to control the proportion of sugar and weight } \\
\text { and in their appropriate management, Rich in Antioxidants. }\end{array}$ \\
\hline $\begin{array}{l}\text { Khadi } \\
\text { herbal } \\
\text { anticellulit } \\
\text { e oil }\end{array}$ & Oil & $\begin{array}{l}\text { Gramodaya } \\
\text { Ashram }\end{array}$ & $\begin{array}{l}\text { Cellulite Oil is specifically formulated to stimulate metabolism in the skin to } \\
\text { dissolve fat and remove toxins. All the herbs in combination perform various } \\
\text { functions to generate heat for proper blood circulation in the affected areas and } \\
\text { activate the sluggish lymph system. }\end{array}$ \\
\hline Slim- & Capsule & $\begin{array}{l}\text { Vitromed } \\
\text { Healthcare }\end{array}$ & $\begin{array}{l}\text { It contains the pure extracts of Chitosan, G. Cambogia, with Folic along with } \\
\text { Psyllium husk, Green Tea extract and Piper nigrum in addition to Aloe vera. It } \\
\text { offers a synergistic and balance approach to diet by cutting the fat intake, } \\
\text { reducing the production and storage of fat while maintaining physical energy, } \\
\text { promotes steady energy levels, \& helps to reduce appetite, increasing lean } \\
\text { muscle, stimulating metabolism and detoxifying the body system. }\end{array}$ \\
\hline $\begin{array}{l}\text { Jatan } \\
\text { capsules }\end{array}$ & Capsule & $\begin{array}{l}\text { Sudha } \\
\text { Herbal }\end{array}$ & $\begin{array}{l}\text { It helps in controlling and normalizing the appetite; as well as providing energy } \\
\text { and a satisfying feeling so that one does not feel constantly hungry. It dissolves } \\
\text { the excess fat gradually. }\end{array}$ \\
\hline Slim Tea & $\begin{array}{l}\text { Medicina } \\
1 \text { tea }\end{array}$ & $\begin{array}{l}\text { Sushilodaya } \\
\text { Inc }\end{array}$ & Herbal Slimming Tea, contains no caffeine. Natural way to weight loss. \\
\hline Obescure & Capsules & $\begin{array}{l}\text { Algen } \\
\text { Exports }\end{array}$ & $\begin{array}{l}\text { Contains standardized extracts of Garcinia, Methi (Trigonella foeneum graecum) } \\
\text { and Garlic. It is a real fat and calorie burner. Garcinia prevents the accumulation } \\
\text { of body fat and deactivates the enzyme that converts excess carbohydrates to fat. } \\
\text { Garlic and methi help in burning risky cholesterol. }\end{array}$ \\
\hline SlimFast & Capsule & $\begin{array}{l}\text { V-Care } \\
\text { Surgical Pvt. } \\
\text { Ltd }\end{array}$ & $\begin{array}{l}\text { It is used as an appetite suppressant and for the weight loss. It increases } \\
\text { metabolism, suppresses appetite, burns calories and increases energy. }\end{array}$ \\
\hline $\begin{array}{l}\text { Fit and } \\
\text { Glow }\end{array}$ & $\begin{array}{l}\text { Softgel } \\
\text { Capsule }\end{array}$ & $\begin{array}{l}\text { Deccan } \\
\text { Healthcare } \\
\text { Pvt. Ltd. }\end{array}$ & $\begin{array}{l}\text { Contains the best source of nature's most vital and essential Omega }-3,6 \text {, and } 9 \\
\text { fatty acids. It is important for the body's biochemistry and assists fat metabolism } \\
\text { for weight loss, Supports healthy blood circulation, Protects against heart } \\
\text { diseases, Helps to fight arthritis \& osteoporosis, Improves joint mobility and } \\
\text { bone density, Lowers blood pressure in hypertension, Supports healthy brain and } \\
\text { memory function, Improves immunity, reduces fatigue. }\end{array}$ \\
\hline $\begin{array}{l}\text { Slim-XL } \\
\text { Capsule }\end{array}$ & Capsule & $\begin{array}{l}\text { Hashmi } \\
\text { Ayurved }\end{array}$ & $\begin{array}{l}\text { It helps to reduce Kapha, which is the basis of fat accumulation, so further fat } \\
\text { deposition will not take place. }\end{array}$ \\
\hline $\begin{array}{l}\text { Raw } \\
\text { Moringa }\end{array}$ & Capsules & $\begin{array}{l}\text { V. J. S. } \\
\text { Pharmaceuti } \\
\text { cals Private } \\
\text { Limited }\end{array}$ & $\begin{array}{l}\text { Contain } 100 \% \text { pure moringa leaf powder. Moringa leaves are the most nutrient } \\
\text { rich part of the plant. It contains: } 7 \text { times the vitamin c found in oranges; } 4 \text { times } \\
\text { the calcium found in milk, and twice the protein; } 4 \text { times the vitamin a found in } \\
\text { carrots, thrice the potassium found in bananas, and thrice the iron found in } \\
\text { almonds. }\end{array}$ \\
\hline $\begin{array}{l}\text { LOMOTO } \\
\text { Capsules } \\
\& \text { Food } \\
\text { Suppleme } \\
\text { nt }\end{array}$ & $\begin{array}{l}\text { Capsule } \\
\text { and } \\
\text { powder }\end{array}$ & $\begin{array}{l}\text { VXL Drugs } \\
\text { and } \\
\text { Pharmaceuti } \\
\text { cals Pvt. } \\
\text { Ltd. }\end{array}$ & $\begin{array}{l}\text { Support healthy slimming efforts along with a balanced lifestyle, Encourage } \\
\text { healthy weight goals without the use of artificial stimulants or ephedra, Promote } \\
\text { efficient metabolism in the body, Support the digestive system by maintaining } \\
\text { the natural breakdown of fats, Promote healthy energy levels through nutrient } \\
\text { absorption, Support balanced sugar levels to prevent cravings. }\end{array}$ \\
\hline OBE Herb & Tablets & $\begin{array}{l}\text { Prasad } \\
\text { Bhavsar, } \\
\text { Ahmedabad, } \\
\text { Gujarat }\end{array}$ & $\begin{array}{l}\text { Capsule contains Garcinia, an herb which has an enormous power to fight fats. } \\
\text { Its main constituent Hydroxycitric Acid (HCA) comes from the rind of Garcinia } \\
\text { fruit. It brings the excessive weight under control by burning fats quickly. It } \\
\text { helps losing weight in a natural way by accelerating the breakdown and dispersal } \\
\text { of fat already laid down. It acts directly on the brain and switch offs appetite. }\end{array}$ \\
\hline
\end{tabular}




\begin{tabular}{|c|c|c|c|}
\hline $\begin{array}{l}\text { Dudhi } \\
\text { Power }\end{array}$ & Tablets & $\begin{array}{l}\text { Isha Agro } \\
\text { Developers } \\
\text { Pvt Ltd }\end{array}$ & $\begin{array}{l}\text { Hepato tonic / diuretic, Helps digestion, dietary fiber, Reduce hunger pangs, } \\
\text { Weight loss. } \\
\text { Bottle gourd is high in dietary fibre, Vitamin C, Riboflavin, Zinc, Thiamine, Iron, } \\
\text { Magnesium, Manganese etc. It is also low in saturated fat and cholesterol. It is } \\
\text { considered to be useful in conditions of constipation, urinary disorders, excessive } \\
\text { thirst due to severe diarrhoea, diabetes. It is also said to help control cholesterol } \\
\text { and considered effective on joint pain and weight loss. }\end{array}$ \\
\hline $\begin{array}{l}\text { Guggulhill } \\
\text { s }\end{array}$ & Tablets & $\begin{array}{l}\text { Isha Agro } \\
\text { Developers } \\
\text { Pvt Ltd }\end{array}$ & $\begin{array}{l}\text { Contains } 1 \% \text { Gugglosterone. Guggul is a very effective herb for maintaining } \\
\text { healthy weight and healthy cholesterol levels. It considered possessing purifying } \\
\text { and rejuvenating properties. It is also useful in reducing symptoms associated } \\
\text { with arthritis, helps maintaining healthy blood circulation etc. }\end{array}$ \\
\hline $\begin{array}{l}\text { Triphalahi } \\
\text { lls }\end{array}$ & Tablets & $\begin{array}{l}\text { Isha Agro } \\
\text { Developers } \\
\text { Pvt Ltd }\end{array}$ & $\begin{array}{l}\text { Contain } 32 \% \text { Tannins. Triphala is considered to be a wonder herb that is } \\
\text { comprehensively used by Ayurvedic physicians to treat various disorders. } \\
\text { Though it is widely used as a laxative. It is also considered to be a powerful body } \\
\text { stimulant that helps promote health and assist in managing overall conditions of } \\
\text { the body. It helps maintain healthy blood circulation. Helps to promote good } \\
\text { colon health. Helps in removing toxins from the body \& increases energy. Helps } \\
\text { to accelerate cleansing activities in the digestive system against gas, bloating, } \\
\text { constipation. Helps to provide overall support for the digestive functions. }\end{array}$ \\
\hline $\begin{array}{l}\text { Guggul } \\
\text { extract }\end{array}$ & $\begin{array}{l}\text { Extract } \\
\text { of Resin }\end{array}$ & $\begin{array}{l}\text { Mother } \\
\text { Herbs Pvt } \\
\text { Ltd }\end{array}$ & $\begin{array}{l}\text { It is carminative, antispasmodic, disphoretic, ecobolic, anti-suppurative and } \\
\text { emmenagogue. Gum resin used for treatment of rheumatoid arthritis. It is a } \\
\text { potent drug for cardiac disorders high cholesterol. It is widely promoted as a } \\
\text { weight loss agent that supposedly enhances thyroid function. }\end{array}$ \\
\hline $\begin{array}{l}\text { Garcinia } \\
\text { Combogia } \\
\text { extract }\end{array}$ & Powder & $\begin{array}{l}\text { Alokik } \\
\text { Herbal } \\
\text { Extract }\end{array}$ & $\begin{array}{l}\text { The rind of this pumpkin like fruit is rich in a substance called hydroxycitric } \\
\text { acid (HCA). It is used as an appetite suppressant and to inhibit the absorption and } \\
\text { synthesis of fat, cholesterol and triglycerides. In other words, it is a dietary aid. }\end{array}$ \\
\hline $\begin{array}{l}\text { Hyaluroni } \\
\text { c acid }\end{array}$ & Tablets & $\begin{array}{l}\text { Chandigarh } \\
\text { Medical } \\
\text { Corporation }\end{array}$ & $\begin{array}{l}\text { Hyaluronic acid tabs are can be taken at any time of the day. It is useful for fat } \\
\text { loss, glowing skin, rejuvenate skin and body, anti ageing. }\end{array}$ \\
\hline Curvy & Oil & $\begin{array}{l}\text { Healing } \\
\text { Herbs }\end{array}$ & $\begin{array}{l}\text { Key ingredients: Extracts of Calendula officinalis (Zergul), Foeniculum vulgare, } \\
\text { Piper nigrum, Zingiber officinale and Rose oil, Sesamum indicum Oil. } \\
\text { This oil helps get rid of cellulite. Cellulite is a series of ripples of fat cells and } \\
\text { fibrous connective tissue under the skin. Usually found on the thighs and butt, } \\
\text { especially in women, it has a characteristic pucker or "orange peel' appearance. } \\
\text { Cellulite is alleged to be a special type of "fat gone wrong," a combination of fat, } \\
\text { water, and "toxic wastes" that the body has failed to eliminate. With massaging, } \\
\text { the cellulite areas are targeted to stimulate circulation, especially for areas not } \\
\text { very well worked with exercise, such as the inside of the knee and upper thigh. }\end{array}$ \\
\hline Lean Care & Capsules & $\begin{array}{l}\text { Sriram } \\
\text { Herbals }\end{array}$ & $\begin{array}{l}\text { Lean Care is a complete natural product and is an extract of quality herbal } \\
\text { ingredients. It does not contain Ephedra and is safe and effective as a weight } \\
\text { regulator through specific ingredients and their unique herbal characteristics. It } \\
\text { helps inhibit the synthesis of fatty acids thereby reducing the fat levels (lipids). It } \\
\text { is highly effective against obesity, hyperlipidemia control, craving for fatty and } \\
\text { sugary foods. }\end{array}$ \\
\hline $\begin{array}{l}\text { BarleyGra } \\
\text { ss }\end{array}$ & Tablets & $\begin{array}{l}\text { Isha Agro } \\
\text { Developers } \\
\text { Pvt Ltd }\end{array}$ & $\begin{array}{l}\text { Reduces levels of low density lipoprotein (LDL) cholesterol (the 'bad' } \\
\text { cholesterol). Helps in reducing fatigue. }\end{array}$ \\
\hline $\begin{array}{l}\text { Phaselous } \\
\text { vulgaris }\end{array}$ & $\begin{array}{l}\text { Powder } \\
\text { (Extract) }\end{array}$ & $\begin{array}{l}\text { Alokik } \\
\text { Herbal } \\
\text { Extract }\end{array}$ & $\begin{array}{l}\text { Active Ingredients: Phaseolin (1\%, } 3 \% \text { HPLC) } \\
\text { The seeds of the White Kidney Bean plant (Phaseolus vulgaris) are most } \\
\text { commonly used in the extract. This extract acts as an amylase inhibitor, } \\
\text { interfering with the enzyme that breaks down carbohydrates into glucose. Thus } \\
\text { eventually converted to fat - they are removed from the body before entering the } \\
\text { blood stream. } \\
\text { Thus this extract promote weight loss by anti-alpha amylase activity (neutralize } \\
\text { the digestive enzyme) }\end{array}$ \\
\hline Curry leaf & Powder & Genius & Curry leaves help to flush out fats from the body. They can reduce the level of \\
\hline
\end{tabular}




\begin{tabular}{|c|c|c|c|}
\hline powder & & $\begin{array}{l}\text { Nature } \\
\text { Herbs } \\
\text { Private } \\
\text { Limited }\end{array}$ & $\begin{array}{l}\text { bad cholesterol in the body. Obese people could liberally consume curry leaves, } \\
\text { which along with healthy diet and exercises could help to reduce weight. }\end{array}$ \\
\hline $\begin{array}{l}\text { Caralluma } \\
\text { extract }\end{array}$ & Powder & $\begin{array}{l}\text { Navchetana } \\
\text { Kendra }\end{array}$ & $\begin{array}{l}\text { Caralluma fimbriata is a succulent plant within the cactus family. It has been } \\
\text { consumed in rural India for hundreds of years in many alternative ways like in } \\
\text { raw type, with a vegetable with spices, or preserved in chutneys and pickles. It } \\
\text { suppresses appetite or hunger throughout operating hours all day. Additionally in } \\
\text { Southern India it is used to enhance endurance. }\end{array}$ \\
\hline $\begin{array}{l}\text { Cell-U- } \\
\text { Loss }\end{array}$ & Tablets & $\begin{array}{l}\text { Herbal- } \\
\text { Nutrition4u }\end{array}$ & $\begin{array}{l}\text { It is an herbal blend that includes corn silk, dandelion, parsley and asparagus, } \\
\text { traditionally used to eliminate excess body fluid. } \\
\text { It reduces water retention associated with normal tissue swelling, by promoting } \\
\text { fluid loss through healthy elimination of water. It supports the reduction of } \\
\text { subcutaneous accumulation of water, which may improve appearance of skin. It } \\
\text { also assists with natural detoxification processes. }\end{array}$ \\
\hline $\begin{array}{l}\text { Real Slim } \\
\text { Oil }\end{array}$ & Oil & $\begin{array}{l}\text { Dhathri } \\
\text { Ayurveda } \\
\text { Private } \\
\text { Limited }\end{array}$ & Oil for weight loss and slimming. Ingredients not mentioned. \\
\hline $\begin{array}{l}\text { Sunova } \\
\text { Bioslim }\end{array}$ & Capsule & $\begin{array}{l}\text { Pixeltech } \\
\text { Solutions }\end{array}$ & $\begin{array}{l}\text { It is an herbal fat and calorie burner. Garcinia prevents conversion of excess } \\
\text { carbohydrates into fat in the body while Plumbago and Embella enhance the } \\
\text { digestion of food. Trigonella reduces blood sugar and in addition also has a lipid } \\
\text { lowering effect. Trikatu increases the bio-availability of above-mentioned } \\
\text { ingredients and promotes the digestion of carbohydrates. }\end{array}$ \\
\hline $\begin{array}{l}\text { Trim } \\
\text { formula }\end{array}$ & Capsule & $\begin{array}{l}\text { Krishna } \\
\text { Herbal } \\
\text { Company }\end{array}$ & $\begin{array}{l}\text { Trim formula correct functions of "Pitta" which functions to increase overall } \\
\text { metabolism and burn the fats. }\end{array}$ \\
\hline $\begin{array}{l}\text { Xtrem } \\
\text { Weight } \\
\text { Loss Oil }\end{array}$ & Oil & $\begin{array}{l}\text { Eye Max } \\
\text { Corporation }\end{array}$ & $\begin{array}{l}\text { For whole body weight reduction in inches which is made with a future herb } \\
\text { called "Garcinia". }\end{array}$ \\
\hline $\begin{array}{l}\text { UD Anti } \\
\text { Cellulite } \\
\text { Gel and } \\
\text { oil }\end{array}$ & $\begin{array}{l}\text { Gel and } \\
\text { oil }\end{array}$ & $\begin{array}{l}\text { Sona } \\
\text { Enterprises } \\
\text { and Ujala } \\
\text { Herbals }\end{array}$ & $\begin{array}{l}\text { Various pure herbs and natural ingredients visibly smoothes, tones, and } \\
\text { retexturizes cellulite-prone skin while detoxifying and discouraging future fat } \\
\text { storage. The Herbal extracts work synergistically to improve circulation, flush } \\
\text { out fat cells, and stimulate the body's natural release of toxins. Body skin appears } \\
\text { tighter, } \\
\text { Key Ingredients: Polysorbate } 80 \text {, Carbopol 940, Triethanolamine, Glycerine, } \\
\text { Herbal Mix (Horsetail, Bladderwrack, Ivy, Laminaria), Herbal Mix (Birch, } \\
\text { Yarrow, Horsetail, Common Nettle, Rosemary, Sage, Lime Tree), Aqua, } \\
\text { Preservatives, Colour and Perfume. }\end{array}$ \\
\hline $\begin{array}{l}\text { SLIMINA } \\
\text {-G Gel }\end{array}$ & Cream & Bio valley & $\begin{array}{l}\text { It is the latest in our revolutionary line of potent fat burner. It is highly effective } \\
\text { topical fat loss formula designed to quickly and safely eliminate fat from those } \\
\text { stubborn areas that remain unaffected by diligent training and dieting. } \\
\text { Ingredients: Extracts of Fucus vesiculosus and Phytolacca berry. }\end{array}$ \\
\hline Guggul & Capsule & $\begin{array}{l}\text { Krishna } \\
\text { Herbal } \\
\text { Company }\end{array}$ & $\begin{array}{l}\text { Extremely useful for all types of inflammation and weight loss. Higher amount of } \\
\text { guggulosterone is responsible for the results. }\end{array}$ \\
\hline $\begin{array}{l}\text { INSTA } \\
\text { TRIM }\end{array}$ & Cream & $\begin{array}{l}\text { Health } \\
\text { Sanctuary }\end{array}$ & $\begin{array}{l}\text { It is an Anti-Cellulite slimming gel that travels deep into the skin where fat } \\
\text { deposits form. INSTA TRIM dramatically helps breaking down these deposits } \\
\text { and encourages collagen growth for smoother skin and reduces the look of stretch } \\
\text { marks to significantly improve the overall appearance of the skin. }\end{array}$ \\
\hline $\begin{array}{l}\text { EVERSLI } \\
\text { M } \\
\text { Slimmin } \\
\text { Tea }\end{array}$ & Powder & $\begin{array}{l}\text { Teleone } \\
\text { Consumers } \\
\text { Product Pvt. } \\
\text { Ltd. }\end{array}$ & $\begin{array}{l}\text { Ever Slim Slimming teas designed to accelerate weight loss. Research shows } \\
\text { drinking two cups of Slim tea every day not only helps shed stubborn pounds by } \\
\text { boosting metabolism, but also blocks the fattening effects of carbohydrates; } \\
\text { promotes strong, healthy teeth; improves cognitive functioning and mental well- } \\
\text { being; clarifies skin, giving it a healthy, radiant glow and strengthens immune } \\
\text { system. }\end{array}$ \\
\hline
\end{tabular}




\begin{tabular}{|c|c|c|c|}
\hline Amazing & Capsule & $\begin{array}{l}\text { Amazing } \\
\text { Herbal } \\
\text { Remedies }\end{array}$ & $\begin{array}{l}\text { Main Ingredients: Guggulu (Commiphora mukul): It is useful in removing fats } \\
\text { from the body. It corrects the liver metabolism and helps the body in removing } \\
\text { fat deposits. Nisonth (Operculina turpethum): It is very useful in fatty liver and } \\
\text { also corrects the fat metabolism in liver. Burns fat in the muscles and liver and } \\
\text { also arrest its production. Vacha (Acorus calamus): It reduces 'bad' LDL } \\
\text { cholesterol and triglycerides, detoxifies the body and has a purgative action. } \\
\text { Punarnava (Boerhavia diffusa): It is diuretic, laxative and stomachic herb. } \\
\text { Other } \\
\text { Motha (Cyperus rotundus), Shunthi (Zingiber officinale), Marich (Piper nigrum), } \\
\text { Chitrak (Plumbago zeylanica), Kutaki (Picrorhiza kurroa), Lashuna (Allium } \\
\text { sativum), Pippali (Piper longum), Vidang (Embelia ribes). }\end{array}$ \\
\hline Slim'n'Fit & Capsule & $\begin{array}{l}\text { Adi Siddhi } \\
\text { Sales } \\
\text { Corporation } \\
\text { - Aloevera } \\
\text { Products } \\
\text { Division }\end{array}$ & $\begin{array}{l}\text { Key ingredients: Aloe vera, Garcinia combogia extract, Stevia extract, Vitamin } \\
\text { C. } \\
\text { It lowers down cholesterol, removes deposited fat quickly. It helps to regulate the } \\
\text { lipid metabolism. It is said to promote normal appetite, good digestion, increase } \\
\text { red blood cells and hemoglobin. It has strong purifying and antioxidant qualities } \\
\text { as well as reducing the overall water content in the body tissues. It also cleanses } \\
\text { the toxins from the blood, tissues, lungs and lymphatic. It oxidizes fat, which is } \\
\text { excreted out of body with stool. It suppresses excessive appetite thereby reducing } \\
\text { weight and curbing extra sugar and food cravings. }\end{array}$ \\
\hline $\begin{array}{l}\text { Hoodia } \\
\text { Gordonii } \\
\text { Plus }\end{array}$ & Capsule & $\begin{array}{l}\text { Global } \\
\text { Pharma }\end{array}$ & $\begin{array}{l}\text { Contains } 400 \mathrm{mg} \text { of certified } 100 \% \text { pure South African Hoodia. } \\
\text { Combined with a reduced calorie diet, it can help to reduce weight by decreasing } \\
\text { your appetite. }\end{array}$ \\
\hline $\begin{array}{l}\text { Sthaulyant } \\
\text { ak }\end{array}$ & Powder & $\begin{array}{l}\text { Krishna } \\
\text { Herbal } \\
\text { Company }\end{array}$ & $\begin{array}{l}\text { Ingredients: Agnimantha, Arjuna, Triphala, Ashok : } 20 \text { gm each, Kalmegh, } \\
\text { Babool, Chitrak, Musta, Vidang, Dalchini, Neem, Brahmi, Shigru, Jamun : } 12 \\
\text { gm each }\end{array}$ \\
\hline $\begin{array}{l}\text { GARCINI } \\
\text { CAPSUL } \\
\text { ES }\end{array}$ & Capsule & $\begin{array}{l}\text { P J Impex } \\
\text { Traders }\end{array}$ & $\begin{array}{l}\text { Blocks lipogenesis effectively. Helps burn more calories and excess fat. Reduces } \\
\text { serum leptin levels. Arrests further weight gain. }\end{array}$ \\
\hline Bio-Slim & Capsule & $\begin{array}{l}\text { Indchromad } \\
\text { ex } \\
\text { Neutraceutic } \\
\text { als Pvt Ltd }\end{array}$ & Contains herbals for weight loss. \\
\hline
\end{tabular}

Though these formulations are covering all the forms of therapies, herbal products are at their top. They are available in the form of tablets, capsules, softgel capsules, powders, extracts, oil, ointments, creams, gel, and tea bags etc. These can be used as food supplements, drug intervention, and external applications. These therapies have led to the broader prospect and wider availability to the patients as well as to healthy people.

\section{CONCLUSION}

Herbal weight loss products are a great safe option for the people who want to lose weight naturally. They are cheap, available easily, and have lesser side effects. There is great market potential for these products. Still more safe, efficacious and affordable products can be prepared on the basis of the traditional knowledge supported by experimental base. Though considerable research on pharmacological and clinical aspect has been carried out on these plants, they may be further explore on the modern scientific approaches for better leads in the health care. This exercise will not only preserve the traditional knowledge but also lead to their increase in the health care system. Production of standardized herbal products will definitely lead India to emerge as major player in the global herbal market.

\section{ACKNOWLEDGEMENT}

Authors would like to acknowledge Prof. MS Baghel, Director, IPGT \& RA for constant support and encouragement.

CONFLICT OF INTEREST: None declared 
${ }^{1}$ Worldwide Obesity Trends - Globesity, 2006. [Available from: htlp://www.annecollins.com/obesity/worldwide-obesity.htm]
${ }^{2}$ World Health Organization, Obesity. preventing and managmg the global epidemic, Report of a WHO consultation on obesity, Geneva, 1998.

${ }^{3}$ D Sathis Kumar, David Banji, Harani A, Physiological factor in obesity, American-Euresian Journal of Toxicolgical Sciences, 2010, 2(3), 177-189.

${ }^{4}$ Centre for Public Health Excellence at NICE (UK), National Collaborating Centre for Primary Care (UK), "Obesity: The Prevention, Identification, Assessment and Management of Overweight and Obesity in Adults and Children," National Institute for Health and Clinical Excellence (UK) (NICE Clinical Guidelines, No. 43), 2006. [Available from: http://www.ncbi.nlm.nih.gov/books/NBK63696/ ]

${ }^{5}$ Obesity and Overweight, Fact Sheet, Number 311, 2012. [http://www.who.int/mediacentre/factsheets/fs311/en/index.html]

${ }^{6}$ Hardeman W, Griffin S, Johnston M, Kinmonth AL, Wareham NJ, Interventions to prevent weight gain: a systematic review of psychological models and behavior change methods. Int J A Review on Obese Relat Metab Disord, 2000, 24, $131-143$.

7 Abdollahi M, Afshar Imani B, A review on obesity and weight loss measures, Middle East Pharmacy, 2003, 11, 6-10.

${ }^{8}$ Swinburn BA, Caterson I, Seidell JC, James WP, Diet, Nutrition and the Prevention of Excess Weight Gain and Obesity, Public Health Nutrition, 2004, 7(1A), 123-146.

${ }^{9}$ Park JP, Kim JH, Park MK, Yun JW, Potential Agents for Cancer and Obesity Treatment with Herbal Medicines from the Green Garden, Biotechnology and Bioprocess Engineering, 2011, 16(6), 1065- 1076.

${ }^{10}$ Ghosh D. A botanical approach to managing obesity. In: Martirosyan DM (Eds.), Functional Foods for Chronic Diseases. Vol 4. Richardson, Texas, USA: Functional Foods Center 2009. P. 263-273.

${ }^{11}$ Amin KA, Nagy MA, Effect of Carnitine and Herbal Mixture Extract on Obesity Induced by High Fat Diet in Rats, Diabetology and Metabolic Syndrome, 2009, 1(17), 1-14.

${ }^{12}$ Hasani Ranjbar S, Nayebi N, Larijani B, Abdollahi M A. Systematic review of the efficacy and safety of herbal medicines used in the treatment of obesity. World J Gastroenterol, 2009, 15(25), 3073-3085.

${ }^{13}$ Phadke AS, A review on lipid lowering activities of Ayurvedic and other herbs, Natural Products Radiance 2007, 6(1), 81-89.

14 Chandrasekaran CV, Vijayalakshmi MA, Prakash K, Bansal VS, Meenakshi J, Amit A, Herbal approach for Obesity management, American Journal of Plant Sciences, 2012, 3, 1003-1014.

${ }^{15}$ Singh BB, Sivarama Prasad Vinjamury, Claudia Der Martirosian, Erica Kubik, Mishra LC, Shepard NP, Singh VJ, Melany Meier, Sonal GM, Ayurvedic and collateral herbal treatments for hyperlipidemia: A systematic review of randomized controlled trials and Quasi experimental designs, Aternative Therapies, 2007, 13(4), 22-28.

${ }^{16}$ Philomena George, Nimmi OS, Cent percent safe centum plants for antiobesity, International Journal Of Innovative Technology \& Creative Engineering, 2011, 1(3), 1-19.

${ }_{17}^{17}$ Dubey NK, Rajesh Kumar, Tripathi Pramila, Global promotion of herbal medicine: India's opportunity, Curr Sci $2004,86(1)$, 37-41.

18 Anonymous. The Drugs and Cosmetics Act and Rules 1945. Delhi: Ministry of Health and Family Welfare, Government of India, 2005.
19

19 Available

from:

http://www.alibaba.com/trade/search?IndexArea=product_en\&SearchText=herbals_for_weight_loss\&atm=\&f0=y\&country=IN 